\title{
STANDARDS OF DISCLOSURE IN PROXY SOLICITATION OF UNLISTED SECURITIES
}

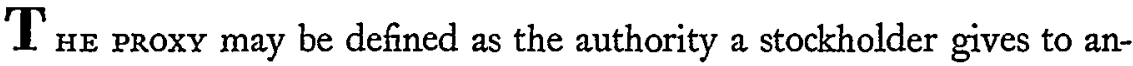
other to vote for him in the affairs of the corporation. It is a form of agency, the proxy holder being an agent with general or special powers. ${ }^{1}$ The proxy thus provides the stockholder an opportunity to participate in the affairs of the corporation when he is unable personally to attend stockholders' meetings. Although virtually every jurisdiction has recognized the utility of the proxy by legislative provision, ${ }^{2}$ it has frequently been misused. Management has often used the proxy to perpetuate itself in office, to formulate and execute self-serving policies, and to render the corporation subservient to its will. These undesirable results are often achieved by withholding vital information from the stockholders, information they should have if they are to make intelligent decisions on whether to grant their proxies. It is not uncommon, for example, for management, as well as other groups that are vying for control, to obtain proxies from apathetic stockholders without relating the slightest information on how they will be voted or who will vote them. ${ }^{3}$

\section{Factors Giving Rise to Inadequate Disclosure}

The widespread failure to give adequate information to stockholders when their proxies are solicited is attributable not only to the apathy of stockholders, but also to many other factors. One contributing influence is the reluctance of the courts to examine proxy solicitation data and pass on the adequacy of disclosure when called upon to do so by an aggrieved stockholder through injunction, quo warranto, or mandamus

\footnotetext{
${ }^{2}$ See Ballantine, Corporations $\$ \$$ I78-8o (rev. ed. r946) [hereinafter cited as Ballantine]; 5 Fletcher, Private Corporations $\$ \S 2055-62$ (repl. vol. 1952) [hereinafter cited as FLETCHER].

"Iowa is the only jurisdiction where the right to vote by proxy is not expressly provided by statute; but the mention of "proxy voting" implies the right. See IowA CODE § 49 r.47 (Supp. x 958 ).

3 "Because many small stockholders almost automatically sign and return the proxy requested by the management, ability to direct the proxy machinery, coupled with a substantial minority of ownership, commonly adds up to ability to choose directors." Berle, "Control" in Corporate Law, 58 CoLUM. L. REv. 1212, 1213 (1958).

See also Berle \& Means, The Modern Corporation and Property 69-125 (r932); Burnham, The Managerial Revolution ch. 8 (x94I).
} 
proceedings. State $v$. Meridit $h^{5}$ illustrates this judicial passivity. In that case the plaintiff and the defendant were the only candidates for election to a vacancy on the corporation's board of directors, and the defendant had been elected by the use of proxies solicited for the election. The plaintiff instituted a quo warranto proceeding to test the validity of the election, alleging that the stockholders who gave their proxies to the defendant were not fully informed of his policies. The proxies were obtained by a peremptory demand made by the defendant in his official capacity as president. The following brief letter contained the only information the defendant gave the stockholders when he solicited their proxies:

Dear Member: The annual meeting of this Association will be held January 18, I916. We would like to have you as a policy holder represented at this meeting. Will you kindly date and sign your name to the attached stamped proxy card and mail to us immediately. . . .

In upholding the election, the court stated: ${ }^{7}$

[W] e are satisfied that so long as the proxy is given by a member having a vote and is his voluntary act, and the written authority is executed and filed in the proper time, the vote is not invalidated because of the improper solicitation of the proxy.

This and similar decisions amount to judicial disenfranchisement of stockholders who depend upon proxy representation as their only means of participating in the affairs of the corporation. ${ }^{s}$ Their right to voice

4It is interesting to note that twelve states have statutes specifically providing for judicial review of corporate elections. They are California, Delaware, Idaho, Montana, Nebraska, New Jersey, New Mexico, New York, North Carolina, North Dakota, South Dakota, and Virginia. Illustrative statutes are DEL. CODE ANN. tit. 8, § 225 (1953); N.C. GEN. STAT. $\$ 55^{-1} 1_{4}$ (1950); N.Y. GEN. CoRP. LAW $\$ 25$. In all other states, resort must be had to common-law proceedings. See, e.g., 5 FLETCHER $\$ 2073$; Aranow \& Einhorn, State Court Review of Corporate Elections, 56 CoLum. L. REv. Is5 (1956).

An excellent discussion of stockholder relief under the Securities and Exchange Commission's proxy rules is found in Aranow \& Einhorn, Corporate Proxy Contests: Enforcement of the SEC Proxy Rules by the Commission and Private Parties, 31 N.Y.U.L. REv. 875 (1956); Loss, The SEC Proxy' Rules in the Courts, 73 HARv. L. REv. 104I (1960).

1 83 Iowa 783,167 N.W. 626 (1918).

${ }^{6}$ No stockholder could make an intelligent decision on whether to give his proxy from the information disclosed in such a letter.

${ }_{1} 83$ lowa at 789,167 N.W. at 627 .

${ }^{8}$ See generally Tilden v. Quaker Oats Co., 1 F.2d 160 (7th Cir. 1924); McClean v. Bradley, 282 Fed. 101I (6th Cir. 1922), cert. denied, 266 U.S. 619 (1924); In re 
their opinions at stockholders' meetings is lost unless they are fairly and fully informed of the policies of the soliciting group.

Another factor that has led to withholding information from stockholders in proxy solicitation is the attitude of management. Looking upon disclosure as a burdensome formality, management welcomes judicial laissez faire and, understandably, declines to assume voluntarily the burden of adequate disclosure." Likewise, the "phenomenal growth in the size of corporations, the number of stockholders, and the widespread geographic distribution of stock ownership," as well as the absence of legislative intervention at the state level, have played their parts in fostering nondisclosure. ${ }^{11}$

\section{Federal Regulation of Listed Securities}

In 1934, Congress passed the Securities Exchange Act, ${ }^{12}$ which contains provisions designed to ensure to the stockholder full and adequate disclosure of material information by soliciting groups. ${ }^{13}$ Section I4(a)

Chilsen, 19 Del. Ch. 398, x68 Atl. 82 (Ch. 1933); Gow v. Consolidated Copper Mines Corp., 19 Del. Ch. 172,189 Atl. $\times 42$ (Ch. 1933); Hexter v. Columbia Baking Co., 16 Del. Ch. 263, 145 Atl. 115 (Ch. 1929); McKee v. Home Savings \& Trust Co., 122 Iowa 73I, 98 N.W. 609 (1904); Schmidt v. Mitchell, xox Ky. 570, 4x S.W. 929 (1897); Bache v. Central Leather Co., 78 N.J. Eq. 484, 81 Atl. 57I (Ch. rgrr); Cone v. Russel, 48 N.J. Eq. 208, 2 I Atl. 847 (Ch. I891); Rabenold v. Associated Gas \& Elec. Co., 266 N.Y.S. 520 (Sup. Ct. 1933).

${ }^{\circ}$ See generally Aranow \& Einhorn, Proxy Contests for Corporate Control 81-84 (1957); 19 Fletcher $\$ \S 9012$, 9013, 9016; LOSs, Securities Regulation 521-23, 618-19 ( 1951 ) [hereinafter cited as LOSS]; BERLE \& MEANs, op. cit. supra note 3 , at $81-89,139,245$; Note, 78 Sol. J. 869,870 (1934).

${ }^{10}$ Aranow \& Einhorn, Proxy Contests for Corporate Control 8x (1957).

11 "Managements of properties owned by the investing public should not be permitted to perpetuate themselves by the misuse of corporate proxies. Insiders having little or no substantial interest in the properties they manage have often retained control without an adequate disclosure of their interest and without an adequate explanation of the management policies they intend to pursue. Insiders have at times solicited proxies without fairly informing the stockholders of the purposes for which the proxies are to be used and have often used such proxies to take from the stockholders for their own selfish advantage valuable property rights." H.R. REP. No. $1_{3} 83,73 \mathrm{~d}$ CoNG., 2d SEss. $13-14$ (1934). See also S. Rep. No. 792, 73d Cong., $2 \mathrm{~d}$ SEsS. 12 (1934).

One writer has gone even further in describing the evils that have resulted from the misuse of the proxy by stating that what developed "was the separation of ownership from control-a genuine revolution in the dynamics of economic institutions." Aranow \& Einhorn, Proxy Contests for Corporate Control 8 i (r957). See also Loss 520-23, 618-19.

${ }_{12} 48$ Stat. 895 (1934), I5 U.S.C. \& $78(\mathrm{n})$ (1958).

13 "In addition to facilitating intelligent voting by the stockholder, the proxy regulations have the further purpose of giving him the opportunity to present proposals for the consideration of his fellow stockholders through the medium of the management proxy 
makes it unlawful to solicit a proxy from the holder of any security registered on a national exchange except in accordance with rules and regulations prescribed by the Commission. ${ }^{14}$ Briefly, the purpose of the proxy rules laid down by the Commission is "the disclosure of information by those who solicit proxies by means of a proxy statement which must accompany each request for a proxy, consent, or authorization ....."

The I934 Act and the rules under it, however, are of limited applicability because they apply only to "registered" or "listed" securities" and do not apply at all if there is no solicitation. ${ }^{17}$ The effect of the

statement." ARanow \& Einhorn, Proxy Contests for Corporate Control 82 (1957). See also Ballantine $\S$ I8I; 5 Fletcher $\S 2052.1$; Wormser, FrankenSTEIN, INCORPORATED I57-58 (I93I); Bernstein \& Fischer, The Regulation of the Solicitation of Proxies, Some Reflections on Corporate Democracy, 7 U. CHI. L. REV. 226 (1940); Dean, Non-Compliance with Proxy Regulations-Effect on Ability of Corporation to Hold Valid Meeting, 24 CoRnell L.Q. 483 (1939); Note, 53 HARv. L. REV. II65 (I940); Note, 33 ILL. L. REV. 914, 922 (1939); Note, 13 ST. JoHN's L. REV. 297 (1939).

It The first of these proxy rules and regulations were published on September 24, 1935, and were kuown as the "LA Rules." They were almost too experimental to be regulatory and required the issuance of a proxy statement that contained a brief description of matters to be considered at the future stockholders' meeting, prohibited false and misleading statements, and required the filing of these materials at the time they were mailed to stockholders. See Exch. Act Release No. 1823 (Aug. I1, 1938); 17 C.F.R. $\$ 240.14 a$ ( 1949 ).

For a comprehensive outline of the history of the SEC proxy rules, see ARANow \& Einhorn, Proxy Contests for Corporate Control 84-90 (1957); Loss 525-35; Bayne, Around and Beyond the SEC-The Disenfranclised Stockholder, 26 IND. L.J. 207 (I95I).

15 Ballantine 414.

${ }^{16}$ Registration on a national exchange is a corporate prerogative. The corporation does not become subject to SEC regulation unless it chooses to do so. See ARANOW \& EinhorN, Proxy Contests for Corporate Control 85 (1957).

Criticizing this characteristic of the SEC proxy regulation, a writer has observed: "It is a strange sort of regulatory scheme which gives individual members of the class to be regulated the power to decide whether the regulation should apply to them." Loss $6 \mathrm{I}_{5}$.

Another writer has maintained that this listing requirement is an unrealistic standard by which to measure the need for proxy regulation. Aranow \& EinhorN, Proxy Contests for Corporate Control 86 (rg57). See also Bayne, supra note I4, at 223 .

17 "Through its administration of the proxy regulations, the Commission has become increasingly aware that some issuers have avoided adequate disclosure to their stockholders by the simple device of not soliciting proxies. This is especially vicious because, in many cases, the failure to solicit proxies prevents the presence of a quorum and thus results in self-perpetuation of management. As a consequence, stockholders are deprived of an opportunity to pass upon the activities of management, and to remove 
listing requirement is to exclude from regulation a vast majority of the corporations in the United States. ${ }^{18}$

Recognizing the evils incident to freedom from regulation, the Securities and Exchange Commission undertook two major studies of the soliciting practices of groups who sought proxies from owners of unlisted securities. ${ }^{19}$ In the first of these studies, an extensive survey was made of all the proxy material distributed to stockholders in 1943 and 1944 by the management of seventy-six domestic corporations with assets worth three million dollars or more whose voting stock had unlisted trading privileges. The findings of the Commission clearly showed the evils resulting from the lack of standards of fair disclosure. Proxy materials distributed in connection with eighty-nine per cent of the annual stockholders' meetings of these corporations did not name the persons for whom the stock would be voted as directors; nor was the interest of officers and directors described in any manner for 151 of the 152 meetings involved. In addition, the Commission found that some ninety-five per cent of the corporations did not afford their stockholders an opportunity to vote yes or no on specific issues through a convenient ballot-type or box-type proxy. ${ }^{20}$

These studies culminated in a report to Congress that recommended an amendment to the I934 Act that would have required companies engaged in interstate commerce to register with the Commission all

bad management from office." SEC, Report on Proposals for Amendments to the Securities Act of 1933 and the Securities Exchange Act of 1934, H.R. Comm. Print, 7 rst CoNG., Ist SESS. 35 (194I). Loss 555-60; Dean, supra note 13, at 487; Bayne, supra note 14 , at 2 ro-r 7 .

In addition, see LatTin, Corporations ch. 7, \& 4 (1959); Aranow \& Einhorn, Proxy Regulations: Suggested Improvements, 28 GEO. WASH. L. REv. 306 (1959); Bayne, supra note I4, at 2 I0-22; Smith v. Republic Pictures Corp., 144 N.Y.S.2d I42 (Sup. Ct. I955).

${ }_{18}$ Bayne, supra note 14, at 223. Another excellent discussion concerning the applicability and coverage of the SEC proxy rules is found in Friedman, SEC Regulation of Corporate Proxies, 63 Harv. L. REv. 796, 814-21 (1950).

10 SEC, A Proposal to Safeguard Investors in Unregistered Securities, H.R. Doc. No. 672, 79th CoNG., 2d SEss. (1946); Sec. Exch. Act Release No. 4399 (Jan. 9, 1950). See also, H.R. Doc. No. 464, 8 xst CoNG., 2d SEss. (x950), embodying President Truman's recommendation to Congress to accept the SEC's proposals.

${ }^{20}$ In addition, the Commission concluded that in only one case was there disclosure of the security holdings of directors and nominees; that none of the proxy statements stated the remuneration of management; and finally, that in a great percentage of the selected materials, the annual report of the company was not sent to the stockholders until after the meeting had been held. SEC, $A$ Proposal to Safeguard Investors in Unregistered Securities, H.R. Doc. No. 672, 79 th CONG., 2d SESS. I8-20 (1946). 
securities not listed on an exchange. ${ }^{21}$ The amendment, however, would have exempted any company with less than three million dollars in assets and three hundred security holders. ${ }^{22}$ These recommendations were not accepted by Congress. Because the majority of corporations are not within the purview of the Securities and Exchange Commission's regulation, stockholder protection must come from other sources-the courts and the legislatures.

\section{Judicial Standards of Disclosure}

Because of judicial reluctance squarely to meet the problem of adequate disclosure in proxy solicitation, there is a paucity of case law available for analysis. In only two jurisdictions, New York and Delaware, have cases arisen that warrant investigation.

${ }^{21}$ In 1950, Senator Frear sponsored a bill to effectuate the requested amendments. S. 2408, S1st CoNG., 1st SEss. (1949). See Loss 613-22; Comment, 45 ILL. L. REv. 263 (1950); Bayne, supra note 14, at 222-30; Gilbert, Management and the Public Shareholder, 28 HARv. Bus. REv. 4, 79-80 (1950).

Similar legislation was unsuccessfully introduced in 1955 by Senator Fulbright based on a study made in 1955 of the stock market. S. REP. No. 2054, 84th CoNG., 1st Sess. (1955). See Aranow \& Einhorn, Proxy Contests for Corporate Control $87(1957)$.

${ }_{22}$ Even as qualified, however, it was estimated that the proposed amendments would have pulled $\mathrm{I}, 75^{\circ}$ additional companies under SEC regulation. SEC, A Proposal to Safeguard Investors in Unregistered Securities, H.R. Doc. No. 672, 79th CoNG,, ad SESS. I7 (1946).

Under the more liberal Fulbright Bill, sapra note $2 \mathrm{I}$, which would have exempted any company with assets of less than $\$ 5,000,000$ or 500 security holders, it was estimated that the SEC's control would have been extended to an additional r200 companies with assets over $\$ 35,000,000,000$. N.Y. Times, May 19, 1956, p. 27 , col. z.

See also Hearings on $S .2408, A$ Bill to Amend the Securities Exchange Act of 1934, 8 Ist CoNG., 2d SEss. 23 (1950), wherein Mr. Loss, speaking in support of the bill, stated, concerning the results of the second SEC study: "We found some improvements over 1946 , but most of the companies, most of the presently unregulated companies, continue to request their stockholders to give their proxies, exercise their corporate franchise, without any adequate information."

Likewise, the New York Stock Exchange has attempted to extend the proxy rules to unregistered companies by requiring members who participate in the solicitation of proxies to file with the Exchange information equivalent to that required by the SEC. As this requirement would apply only to contested solicitations, however, it would have no teeth in it as a regulatory measure. Loss $488-89,494,528$. For the part the New York Stock Exchange played in the SEC amendment program, see Loss 247-53.

See also Gilbert \& Gilbert, Sixteenth ANNual Report of Stockholders' Activities at Corporate MeETings i 84 (1955); Emerson \& Latcham, Proxy Contests: Competition for Management Through Proxy Solicitation, S Sw. L.J. 403 (1954) (an interesting and practical survey of 1953 and 1954 proxy contests). 
A. Delaware Cases

In Empire So. Gas Co. v. Gray, ${ }^{23}$ the plaintiff alleged that the soliciting group had led stockholders to believe that they possessed authority from the board of directors to solicit their proxies when in fact they did not. The gravamen of the action was fraudulent use of the corporate name and authority. The solicitation data was untruthfully signed, "By Authority Of The Board Of Directors," and contained only the following information: (I) a request to stockholders to execute and return the enclosed proxy if they wished their stock voted; ${ }^{24}(2)$ a statement that the expense of the proxy solicitation would be paid by the corporation; and (3) the name of one person who was to be elected a director of the corporation. ${ }^{25}$ The Delaware Court of Chancery held that the soliciting group misrepresented a material issue when it led stockholders to believe that the solicitation data was issued by the authority of the management; that soliciting groups have the burden of avoiding statements that are misleading; and that the burden cannot be put on stockholders to be "eternally vigilant" against deception. ${ }^{26}$ The misrepresentation-of-a-material-issue test, however, does little to guarantee the stockholder enough information to make an intelligent choice, for it only assures him that what is disclosed is not misrepresented.

In Kaufman v. Shoenburg, ${ }^{27}$ the defendant officers sought the adoption of a stock option plan in which they, as officers of the corporation, would have participated. At the time, there was an incentive compensation plan already in operation, but the defendants were soliciting proxies without informing the stockholders of this similar plan. The plaintiff, seeking to enjoin the passage of the second plan, charged that

${ }^{23} 29$ Del. Ch. 95, 46 A.2d 741 (Ch. 1946).

${ }^{24}$ Id. at 104, 46 A.2d at 745 .

It is interesting to note the language used by the soliciting group here. The stockholder is told, in essence, that he either votes by returning the proxy or does not vote at all. This somewhat coercive persuasion is indicative of the practices indulged in by many groups when proxies are solicited. One judge has most appropriately described it as "a battle of proxies and not of wits." Berendt v. Bethlehem Steel Corp., ro8 N.J. Eq. 148, 151, 154 Atl. 32 I, 322 (Ch. I931).

${ }^{25}$ The information disclosed to the stockholder in this case can hardly be expected adequately to inform any security holder of the issues upon which he is expected to vote. The return of a proxy in response to this solicitation can only be considered an automatic response due to stockholder inertia.

${ }_{20} 29$ Del. Ch. 95, 106, 46 A.2d 741, 746 (Ch. 1931).

${ }^{27} 33$ Del. Ch. 211,91 A.2d 786 (1952). 
the defendants' failure to advise stockholders of the existing corporate policy of incentive compensation was a deliberate bad faith omission of material information. ${ }^{28}$ Pointing out that the proxy statement referred to "additional compensation" received by the directors, the Court of Chancery concluded that the omission of an explicit reference to the existing profit-sharing plan was not material. ${ }^{20}$ The language of the opinion, however, clearly indicates that the omission of material information from a proxy statenient would be sufficient to invalidate the proxy.

The combined effect of the Gray and Kaufman cases, therefore, is that materiality embraces omissive as well as affirmative misrepresentations. ${ }^{30}$ Though vague, the present Delaware test of adequate disclosure affords some guarantee to the stockholder that he will not be

${ }^{28}$ It should be noted here that inadequate disclosure may occur in one of three ways:

(x) Probably the most common type of disclosure is partial disclosure. Here the soliciting group gives the stockholder some information, but there simply is not enough for an intelligent election. This is the most damaging since it is the hardest of the three to check. There is no fraud, misrepresentation, or deliberate omission; thus the courts find it extremely troublesome.

(2) The second and most fiagrant type of inadequate disclosure is that which includes fraudulent and misleading statements. Here statements are made to deceive the stockholder into giving his proxy. Courts have little or no trouble at all invalidating proxies so acquired.

(3) Deliberate omission of important information, that information which, if given, may very well keep the stockholder from returning his proxy, gives the courts little trouble. Some courts, however, place a heavy burden on the stockholder to prove the omitted material significant and the omission fraudulent. See, e.g., Schlensky v. South Parkway Bldg. Corp., 350 III. App. 293, 112 N.E.2d 7×6 (1953). Contra, In re Scheuer, 59 N.Y.S.2d 500 (Sup. Ct. 1942 ).

${ }^{29} \mathrm{An}$ interesting and related problem concerning the adequacy of disclosure in the ratification of executive compensation is found in O'Neal, Stockholder Attacks on Corporate Pension Systems, 2 VAND. L. REv. 35I, 376 (1948), where the author states:

"The information most likely to be concealed is, of course, participation of officers or directors in pension benefits, the size or cost of their pension and the nearness of key personnel to the retirement age. It would appear that where executives or directors are to benefit from a pension plan the communications disclosing their interest 'must lay bare the truth without ambiguity or reservation in all its stark significance'."

See also Rogers v. Guaranty Trust Co., 288 U.S. 123 (1933); Washington \& Rothschild, COMpensating the CoRporate Executive 197-206, 264, 353-55 (rev. ed. 195 I).

${ }^{30}$ The extension of the doctrine of inateriality to cover omissions as well as affirmative misrepresentations does much to aid the stockholder, but the damage done by so many soliciting groups by merely giving little or no information to the stockholder is not corrected by this extension. An excellent example is Berendt v. Bethlehem Steel Corp., ro8 N.J. Eq. I48, I54 Atl. 32 I (Ch. 193 I). 
deceived and that, in most instances, he will be given enough information to make an informed decision when his proxy is solicited. ${ }^{31}$

\section{B. New York Cases}

The development of the New York rule may be traced by a chronological examination of four cases. In the first case, In re Scheuer, ${ }^{32}$ the solicitation data provided stockholders included statements of an alleged decline in earnings due to the cost of new equipment that had been deducted from gross earnings. In truth, the expenditures were charged to capital. ${ }^{33}$ An aggrieved stockholder brought an action to have the proxies so solicited declared invalid. The New York Supreme Court stated that: ${ }^{34}$

$[T]$ he activities of the campaign managers ... resulted in deviations from the exacting standards of fairness now generally agreed as incumbent upon those engaged in securing proxies.

However, the court not only failed to relate the nature of this "general agreement," but also declined to enumerate the particulars of these "exacting standards." Thus, the decision did little to establish a workable standard of disclosure.

A more realistic and less uncertain standard of disclosure emerged from the second case, Continental Bank E Trust Co. v. '200 Madison Ave. Corp., ${ }^{35}$ where it was alleged that the soliciting group misrepresented their voting strength as well as the earning power of the corporation in order to obtain proxies. ${ }^{36}$ Excluding from consideration what

${ }^{3 x}$ The Delaware view of materiality has been employed in a broader sense by other jurisdictions. These cases have generally held that the stockholder must be given enough information for an intelligent vote, but are limited principally to ratification. See, e.g., Gottlieb v. MoGee, 34 Del. Ch. 537, I07 A.2d 240 (Ch. 1954); Kerbs v. California E. Airways, 33 Del. Ch. 395, 94 A.2d 217 (Ch. 1953); Winchell v. Plywood Corp., 324 Mass. 171, 85 N.E.2d 313 (1949); Rosenfeld v. Fairchild Engine \& Airplane Corp., 284 App. Div. 20r, 132 N.Y.S.2d 273 (1954), aff'd, 309 N.Y. 168, 28 N.E.2d 291 (1955).

But see Schlensky v. South Parkway Bldg. Corp., 350 II1. App. 293, Ir2 N.E.2d 716 (1953). See also Demmler, Private Suits Based on Violations of the Proxy Rules, 20 U. PITT. L. REv. 587 (1959).

3259 N.Y.S.2d 500 (Sup. Ct. I942).

${ }^{33}$ Furthermore, the data repeated laudatory statements about the soliciting group uttered by a brokerage firm that had been paid for its praise.

${ }^{34} 59$ N.Y.S.2d 500, 50r (Sup. Ct. 1942).

${ }^{35} 43$ N.Y.S.2d 402 (Sup. Ct. 1943 ).

${ }^{30}$ The court pointed out that this was not important since at all times the voting strength was substantial. As to other types of fraud in the solicitation of proxies that may warrant vitiation of the proxies, see Lyon v. Holton, 167 Misc. 585,4 . N.Y.S.2d 
it termed the "unimportant and inconsequential variances"37 of the solicitation data, the New York Supreme Court concluded that there was no fraud by way of concealment of material facts. Furthermore, the court declared, none of the statements alleged to be untrue "would influence any layman to give his proxy where he would not otherwise have done so."38 Evidently, the court deemed it necessary not only to find a material misrepresentation but also an inducement of the stockholder to give his proxy in reliance on the misrepresented statements. Although a significant improvement over Schever and the first real effort on the part of the New York court to establish a general standard of disclosure, the case leaves many questions unanswered. ${ }^{30}$

Two years later, in Wyatt v. Armstrong, ${ }^{40}$ the same court disregarded the language of the Madison Avenue case and spoke once again in the tradition of the Schewer case when it announced that a corporate election wherein proxies were used would be set aside if the methods of obtaining the proxies were "so clouded with doubt and tainted with questionable circumstances that the standards of fair dealing"111 had been violated. As in Scheuer, the court failed to spell out the nature and scope of these "standards." In concluding, however, that the defendants were guilty of concealment amounting to misrepresentation and fraud, the court exhibited an attitude inclined to protection of stockholders. It announced that the stockholders were deprived "of their freedom to vote at corporate elections in the light of a complete disclosure of all relevant facts and circumstances." 42 The court's conclusion merely states what all acknowledge to be the desired end. What the court declined to do, however, was to recite a workable standard whereby those who seek proxies will know what degree of disclosure is "complete."

$53^{8}$ (Sup. Ct. 1938) (concerning the concealment of a fraudulent corporate purchase); Segel v. Bresnick, 127 N.Y.L.J. 1551 (N.Y. Sup. Ct. 1952).

${ }^{37} 43$ N.Y.S.2d 402,406 (Sup. Ct. 1943 ).

${ }^{38}$ Id. at $407-08$.

${ }^{38}$ For instance, the court, instead of speaking in terms of materiality, relevancy, or similar labels, should have discussed whether a minimum standard of disclosure should be laid down to cover future cases, protection of the stockholders, how much they should be told in particular situations, and the duty of management to do so. These cases should be decided only after a look at the overall picture of inadequate disclosure. The imposition of a policy favoring fair and full disclosure should be the principal consideration, and with this would come relief in the particulars.

${ }^{40} 186$ Misc. 216,59 N.Y.S.2d 502 (Sup. Ct. 1945).

${ }^{41} \mathrm{Id}$. at 220,59 N.Y.S.2d at 505 .

${ }^{42} I d$. at 224,59 N.Y.S.2d at 508. 
In the last case of the series, In re Hoe $\mathrm{G} \mathrm{Co}^{2},{ }^{43}$ the present New York rule was enunciated. Here a stockholders' committee obtained control of the board of directors. Some of the members of the defeated management group petitioned the court to have the election set aside on the ground that the committee's solicitation data contained false statements against the management. Relief was denied. The court held that the result of action taken by stockholders will not be disturbed unless it is clearly established that the solicitation was so tainted with fraud that an inequitable result was accomplished. ${ }^{44}$

\section{Other Applicable Proxy Principles}

Many cases do not discuss what constitutes adequate disclosure, but afford relief by the application of well-settled principles of the law of proxies. Generally, the use of the proxy is limited to participation in the ordinary, as opposed to the extraordinary, affairs of the corporation. Affairs that have been held to be outside the scope of the proxy power include the power to vote on reorganization, ${ }^{45}$ sale of assets, ${ }^{46} \mathrm{con}$ solidation, ${ }^{47}$ and dissolution. ${ }^{48}$

One rule that may be even more significant here is that one may not vote the proxies he holds to benefit himself unless his interest is disclosed. ${ }^{49}$ The application of this rule to the problem of standards of disclosure is weakened, however, because this self-interest must only be disclosed at the time of the vote and not necessarily at the time the proxy is solicited. ${ }^{50}$

${ }^{43} 137$ N.Y.S.2d 142 (Sup. Ct. 1954), aff'd, 285 App. Div. 927, 139 N.Y.S.2d 883 (ist Dept.), aff'd, 309 N.Y. 7×9, 128 N.E.2d 420 (1955).

For an interesting approach to several of these New York cases, see ARANOW \& Einhorn, Proxy Contests for Corporate Control 160-61 (1957).

"It is evident that such a rule is far too broad to be helpful. Adherence to such a standard, if it may be so termed, can only result in additional confusion and indecisiveness and eventually lead the courts farther away from the realization of an equitable and workable standard. What is "so tainted with fraud" is no less uncertain than what is "material."

See Loss $541-43$.

${ }^{25}$ Farish v. Crenegruta Copper Co., 12 Ariz. 235, roo Pac. 78 I (1909).

${ }^{16}$ Moore v. Ensley, II2 Ala. 228, 20 So. 744 (1896).

${ }^{17}$ Fidelity Bldg. \& Loan Ass'n v. Thompson, Ir9 Mo. 668, 25 S.W. 2 1 x (19x8).

${ }^{48}$ McKee v. Home Savings \& Trust Co., 122 Iowa 731,98 N.W. 609 (1904). But see Josephson v. First Nat'l Bank, 42 N.J. Super. 46r, 127 A.2d 2 Io (1956), concerning a change in the number of directors.

${ }^{40}$ Blair v. F. H. Smith Co., 18 Del. Ch. 150, 156 Atl. 207 (Ch. 1931); Lowman v. Harvey R. Pierce Co., $276 \mathrm{~Pa} .{ }_{3} 82$, 120 Atl. 404 (1923).

${ }_{5}{ }_{5}$ FLETCHER $\$ 2060$; LOSS 521 ; LATTIN, op. cit. supra note 17 , at 308-09. 
Finally, general proxy power must be specifically negatived, or the proxy holder will have wide latitude on how to vote. ${ }^{51}$

\section{'Permissible Puffing' of Proxy Data}

It is interesting to note the limits to which a soliciting group may go in advocating its cause. This question gains added significance in light of the New York and Delaware rules, where words such as "materiality," "relevancy," and "fraud" play major roles. One court, as in the Gray case, may emphasize stockholder protection and place the burden on the soliciting group to avoid misleading statements. Other courts, however, exhibit an attitude more favorable to soliciting groups and decline to recognize criteria such as those suggested in Gray. This was illustrated in Kerbs v. California E. Airways, ${ }^{52}$ where, in considering allegedly fraudulent and misleading statements made by the soliciting group, the court commented :53

The matter must be viewed ... with a realization that, as in other types of campaigns, the verbal niceties are not always observed. There is almost necessarily an area of what might be called 'permissible puffing' of one's candidacy.

A third group of courts has gone even further, making stockholder relief almost impossible. In Schlensky v. South Parkzoay Bldg. Corp. ${ }^{54}$ the Illinois Appellate Court stated:

[S] ufficiency of disclosure is only one element to be considered when inquiry is made into the propriety of the transaction. The directors are not bound to disclose to the shareholders every business transaction engaged in by the corporation during the year.... No shareholder was under any compulsion to execute a proxy. It must be presumed that the shareholders who gave proxies in response to the letter ... were satisfied with the disclosure of the facts contained in the letter.

${ }^{51}$ Tilden v. Quaker Oats Co., I F.2d 160 (7th Cir. 1924), (where it was held that this latitude included the power to vote on ratification of management action); Mutual Res. Fund Life Ass'n v. Taylor, 99 Va. 208, 37 S.E. 854 (rgor). Cf. Rice \& Hutchins, Inc. v. Triplex Shoe Co., I6 Del. Ch. 298, 147 Atl. 317 (Ch. 1929).

An interesting and lengthy discussion of these principles is found in Axe, Corporate Proxies, 4 r Mich. L. Rev. 38 ( 1942 ).

See Demmler, sutpra note $3 \mathrm{r}$; LatTin, op. cit. supra note 17 , at 306.

${ }^{53} 33$ Del. Ch. 395, 94 A.2d 217 (Ch. 1953). A similar diversity exists in New York courts. Compare In re Hoe \& Co., 137 N.Y.S.2d r42 (Sup. Ct. 1954), aff'd, 285 App. Div. 927,139 N.Y.S.2d 883 (rst Dept.), aff'd, 309 N.Y. $7 \times 9,128$ N.E.2d 420 (1955), with In re Scheuer, 59 N.Y.S.2d 500 (Sup. Ct. 1942).

${ }_{53} 33$ Del. Ch. 395, 94 A.2d 2r7, 2 r8 (Ch. r953).

${ }_{54} 350$ III. App. 293, 298, rr2 N.E.2d 7r6, 717 (r953).

${ }^{5}$ Id. at 298 , I 22 N.E.2d at $72 x$. 
This relatively recent case unjustly shifts the burden to the stockholder, giving him the choice of personally voting his stock, which is a virtual impossibility in many instances, giving his proxy in silence, or not voting at all. In addition, the court placed great emphasis on the fact that there was no specific allegation that the failure to disclose was wrongful, treating such an allegation as a prerequisite to recovery. In the Scheuer case, however, the court granted relief where the solicitation materials were false and misleading regardless of whether the statements were made "carelessly, recklessly, or deliberately."

\section{Application of the SEC Proxy Rules to UnListed Securities}

To what extent have the state and federal courts deferred to the standards of the Securities and Exchange Commission when considering the adequacy of disclosure in the solicitation of proxies of unlisted securities? Whether these standards could or should be used is a question on which the courts have remained relatively silent. ${ }^{57}$ Generally, however, the SEC rules have been treated as exclusively federal in application. ${ }^{\mathbf{5}}$

This question was squarely presented in Bresnick $v$. Home Title Guar. Co. ${ }^{59}$ The plaintiff's basic contention was that the proxies were obtained "improperly, unfairly, and illegally." It was strongly urged that the SEC rules should guide the court even though the securities involved were unlisted. Disregarding this contention, the court stated that "the test is not compliance with the technical rules, but rather whether the proxy-soliciting material was so tainted with fraud that an

\footnotetext{
${ }^{50}$ In re Scheuer, 59 N.Y.S.2d 500, 501 (Sup. Ct. I 942).

${ }^{67}$ At least one case has arisen where the language of the court implied that, if the occasion presented itself, the proxy rules would be considered. In O'Connor v. Fergang, 14 Misc. 2d 1095, r097, I 82 N.Y.S.2d 942, 944 (Sup. Ct. 1958), the court stated:

"Be it noted that in this case the notices and proceedings were not subject to the Securities Exchange Commission Regulations. But even accepting such standards, the communications here do not vary substantially from other proxy battles under S.E.C. Regulations."

${ }^{68}$ Section 27 of the Securities Exchange Act of 1934 provides that the district courts of the United States shall have exclusive jurisdiction over violations of the proxy rules. On the basis of this section, state courts have declined to consider such violations when passiug upon the adequacy of disclosure. Standard Power \& Light Corp. v. Investment Associates, 29 Del. Ch. 225, 5 I A.2d 572 (Ch. 1947), affirming 29 Del. Ch. 225, 48 A.2d 501 (1946); Eliasburg v. Standard Oil Co., 23 N.J. Super. 431, 92 A.2d 862 (x952), aff'd, x2 N.J. 467, 97 A.2d 437 (1953); In re Hoe \& Co., 137 N.Y.S.2d 142 (Sup. Ct. 1954), aff'd, 285 App. Div. 927,139 N.Y.S.2d 883 (rst Dept.), aff'd, 309 N.Y. $7 \times 9,128$ N.E.2d 420 (1955).

175 F. Supp. 723 (S.D.N.Y. 1959).

${ }^{\circ 0}$ Id. at 724 .
} 
inequitable result was accomplished." In thus dismissing the SEC rules as "technical," the court preserved the integrity of the New York standard, and, in a brief opinion that cited no cases for support, ignored the basic problem. Representing, as they do, the combined knowledge of experts in the field of securities regulation and the product of exhaustive research, it appears that, even in the absence of legislation, the rules of the Securities and Exchange Commission should be used in the state courts as a guide to what is practical and desirable practice.

\section{State Legislative Standards}

The proxy is the creature of the legislature, as its use was not permitted at common law. ${ }^{62}$ Today, there are provisions in every jurisdiction, except one, ${ }^{63}$ expressly authorizing the use of the proxy. These statutes, however, generally deal only with the form, sufficiency, and revocability of the proxy and, with few exceptions, are silent on the problem of adequate disclosure. ${ }^{64}$

California was the first state to take significant action on the problem when it enacted the following statute: ${ }^{65}$

In soliciting proxies authorizing the holder thereof to vote in favor of any amendment to the articles [of incorporation] ... or in soliciting written consents of shareholders thereto, the corporation shall mail to each shareholder of the corporation ... a concise summary of the proposed amendment and the changes proposed to be effected thereby in the rights of the shareholder.

\footnotetext{
${ }^{61} I d$. at 725 .

${ }^{62}$ Re Dean and Chapter of Fernes, Davies Rep. I16 (1607); Taylor v. Griswold, 2 Green 222 (N.J. I 834 ).

${ }^{\text {Bs }}$ See note 2 suppra.

o4 The statutes of several jurisdictions simply authorize proxy voting and no more. Illustrative are ALA. CODE tit. Io, $\$ 38$ (Supp. 1955); HAWAII Rev. LAWS $\$$ 172-24 (1956); Mich. Comp. Laws $\S 450.32$ (1956); Miss. Code ANN. $\S 5326$ (1956); NEb. Rev. Stat. § 21-135 (1954); R.I. GeN. LAWS ANN. § 7-4-2 (1956); UTAH CODE ANN. § 16-2-40 (1953); Wyo. Comp. Stat. ANn. § 17-1 2 (1959).

The statutes of the remaining jurisdictions include provisions which vary in their requirements, but usually include sections concerning written appointments, periodic validity, appointment of more than one proxy, and sale of assets. Almost all the more complicated statutes have provisions concerning the termination of the proxy. For a look at some of the more exhaustive statutes, see ILL. REV. STAT. ch. $32, \S 157.28$ (1957); N.J. Rev. Stat. § 14:10-9 (Supp. 1957); N.C. GeN. STAT. § 55-68 (Supp. 1955).

${ }_{65}$ CAL. CORP. CODE ANN. $\S_{3637}$ (1956).
} 
Although the California statute is limited to assuring adequate disclosure in only one situation, that concerning the amendment of the articles of incorporation, the legislature has at least undertaken to enact some remedial laws.

Oklahoma followed California with a statute that closely parallels that of the latter ${ }^{66}$ and is limited to disclosure requirements when amending the articles of incorporation. ${ }^{67}$

The actions of California and Oklahoma represent the only state legislative activity on the problem. It would seem that the burden of prescribing the standards of disclosure should fall on the legislatures rather than the courts, because the real need is protection of stockholders as a class through a unified system of regulation rather than protection of the individual stockholder through judicial relief.

\section{SUMMARY}

From the above analysis, it appears that a legislative and judicial change of policy toward standards of proxy solicitation is long overdue. Only through the achievement of workable standards that have for their purpose a guarantee to the stockholder of enough information to enable him to exercise his franchise effectively and intelligently will control once again be placed in the hands of ownership, where it rightly belongs. The following suggestions are designed to effectuate such standards:

(I) The Securities Exchange Act should be amended to require that adequate disclosure be made regardless of whether there is a solicitation.

(2) Legislation should be enacted to bring large, publicly-owned corporations within the purview of the Securities and Exchange Commission regardless of whether their stock is listed or registered on a national exchange.

(3) The federal listing requirement should be made more realistic, making the size of the corporation or the number of stockholders the criteria of registration.

(4) The state courts should insure protection to the stockholder through the establishment of minimum standards of disclosure or, in the alternative, consider the proxy rules of the Securities and Exchange Commission when passing upon the adequacy of disclosure in solicitation.

(5) The state legislatures should enact appropriate legislation calling for minimum disclosure requirements.

\footnotetext{
${ }^{\circ 0}$ OkLa. Stat. ANN. tit. $18, \$$ I.154 (195I).

${ }^{\circ 7}$ For an interesting discussion of the Oklahoma statute, see vliet, The Oklahoma Business Corporation Act (pt. I), 2 OKLA. L. REv. I (1949).
} 